\title{
Sculptures do not speak. The Balega made them speak
}

\author{
Art, Text, and Context
}

Daniel P. Biebuyck

\section{(2) OpenEdition}

\section{Journals}

Édition électronique

URL : https://journals.openedition.org/clo/487

DOI : $10.4000 /$ clo.487

ISSN : 2266-1816

\section{Éditeur}

INALCO

\section{Édition imprimée}

Date de publication : 15 janvier 2010

Pagination : 69-83

ISBN : 978-2-85831-196-5

ISSN : 0396-891X

\section{Référence électronique}

Daniel P. Biebuyck, «Sculptures do not speak. The Balega made them speak », Cahiers de littérature

orale [En ligne], 67-68 | 2010, mis en ligne le 20 septembre 2012, consulté le 02 juillet 2021. URL:

http://journals.openedition.org/clo/487 ; DOI : https://doi.org/10.4000/clo.487

Ce document a été généré automatiquement le 2 juillet 2021.

\section{(c) $(1) \Theta$}

Cahiers de littérature orale est mis à disposition selon les termes de la Licence Creative Commons Attribution - Pas d'Utilisation Commerciale 4.0 International. 


\section{Sculptures do not speak. The Balega made them speak}

Art, Text, and Context

Daniel P. Biebuyck

\section{NOTE DE L'AUTEUR}

The word Balega means "The people".

Bwami is (like) the lukundu tree; ${ }^{1}$

it has made its aerial roots reach far. ${ }^{2}$

You see our mulyepo loincloth, but not our testicles. ${ }^{3}$

Those suffering from fear of heights do not reach the summit;

they turn back at the intersections of the branches. ${ }^{4}$

1 The Lega people inhabit the mainly forested highland and lowland regions of Southern Kivu and Manyema in the center-east section of the DRC. At the time of my research (1951-1953, 1955, 1957), they formed a large cohesive and contiguous population located in the then administrative divisions (territoires) of Mwenga, Shabunda and Pangi.

2 In the world at large and among scholars, collectors, and museum experts, the Lega have come to acquire great fame as creators of small, stylized sculptures, including maskettes and masks, anthropomorphic and zoomorphic figurines, and an impressive variety of objects such as spoons, pegs, trumpets, dice, hammers, knives, billhooks, pestles and small four-legged stools, etc. In addition to the sculptures, the Lega produce a host of ephemeral, artistically arranged assemblages, and they use numerous natural objects (plain or modified).

3 The Lega classify these various morphological categories by using distinctive generic terms that do not refer to the forms per se. Thus, for example, the term used for figurines, iginga, means "what sustains"; the term applied to ivory/bone maskettes, lukungu, means "skull". 
These sculptures are carved in wood, elephant ivory and bone, more rarely in stone, clay or fungus; occasionally a figurine is made in leopard or antelope bone, or a mask is manufactured from elephant hide. The ivories (figurines, masks and other items) are admired in the Western world (the Lega themselves do not indulge in aesthetic appraisal) for their smooth, shiny surfaces, and the range of glossy reddish, brownreddish and honey patinas (which fakers and imitators try to duplicate with mixed success). These fine patinas are the result of the repeated processes of oiling (oils mixed with various dosages of redwood powder, reddish and yellowish berries and saps of lianas and trees, and/or reddish river and other lateritic sands) and perfuming the ivory figurines in a rite called "to imbue with oil; to bring in harmony" (kubongia masengo). ${ }^{5}$ The wooden figurines that are part of collectively-owned baskets are mostly rubbed with some kaolin or, more rarely, with red powder.

5 Typical for the ivory figurines is their compactness, the whimsical treatment of the human figure, and the absence of accumulations (except for resin, small beads, cowry shells, or plaited skullcap). With some remarkable exceptions, the wooden figures contained in collectively owned baskets show a fairly crude appearance and a rough surface. The wooden masks and maskettes, the individually owned wooden figurines and the wooden animal figurines, however, have smoother surfaces. Conspicuous for their concave, cordate, mostly whitened faces, the maskettes are generally enhanced with a fiber beard.

6 All sculptures are exclusively and specifically created for the membership of the hierarchically organized voluntary association called bwami (Biebuyck, 1973). This association is, in principle, accessible at all levels for every circumcised male, for an initiate's sister or niece (at the lower grades), and for one or more of his wives (at the three higher grades of ngandu, yananio and kindi). No single bwami status is inherited; all statuses are achieved through initiation (mpala). A person's eligibility for initiation is conditioned by social, economic, and individual factors such as: the support from agnatic and cognatic kin and related and non-related high initiates; the accumulation of goods used as gifts and fees and the availability of large quantities of food (plantains, dried and fresh game meat, goats, salt, oil); the manifestation of desired character traits, a strong moral fiber, and an ability to persevere. As one moves up the hierarchical ladder, the economic, social and moral requirements are more and more rigid. In addition, a man is never fully initiated to the highest kindi grade unless at least one of his spouses succeeds in achieving the highest female grade (bunyamwa). As a result, very few individuals manage to reach the top.

7 As is revealed in their extensive epic literature, the Lega, at one time, were a warlike people and then bwami - which, according to its members, "has no inventor" and was "a fruit that came from above" - brought harmony and peace within and across autonomous groups. In the polysegmentary lineage society of the Lega, without a centralized sociopolitical framework, the bwami fulfilled a basic integrative function in all spheres of life: economic, social, political, legal, ritual, artistic, ethical, educational, ideological, and recreational (Biebuyck, 1973, 1986). The bwami association existed everywhere, with numerous regional, even local, nuances, among the many autonomous subdivisions and branches of society. Notwithstanding regional differences in actual organization and degree of elaboration, the basic structural, functional, contextual and ideological frameworks were identical wherever Bwami existed. 
8 Bwami - the Lega and Bembe say - is learning of the principles of conduct and the profound meanings of things (mahano); it is the acquisition of knowledge (m'maindo); it is enlightenment (kalenganyo). Speaking about the noninitiate, they say: "Know whence you have come: complete darkness blinded your eyes." Speaking about the noninitiate and the initiand, the initiates say: "Let us remove his heart of feathers and let knowledge remain in him" (the noninitiate is considered to be an ignorant weakling; the initiations will transform him into a man).

9 All initiations, from the lowest to the highest levels, from the simplest to the most complicated, are structured like dramas around varied combinations of verbal, kinetic, and musical activities, and iconic displays. The aim is to formulate and to interpret in multiple symbolic ways principles, moral and philosophical values and rules of bwami, to each and inculcate them, and to bestow upon the initiates the paraphernalia pertinent to their grade level together with their symbolic references, and to convey the resulting power, prestige and privileges. The verbal exegesis rests on innumerable aphoristic statements, which are sung and interpreted in dance and action (Biebuyck, 1973, 1986).

10 Across Legaland, there is also uniformity in the types of artworks associated with bwami, their styles and morphology, their use, functions and meanings. The sculptures cannot be classified - as they have been in various art books, exhibition and sales catalogs - as nkisi or bwanga power objects, ancestral cult figures or portraits, spirits or fetishes, representations of deities or heroes, fecundity symbols, divination devices, domestic protectors, or as protective amulets. Rather, like every other natural or manufactured item, all the sculptures function as initiation objects (masengo) linked with closed rites and with individual status within the bwami association (Biebuyck, 1973, 1986, 1994, 2002). They are secret and imbued, like the initiations themselves, with an aura of sacredness, danger, and mystery. These small and portable objects are not on public display, but they are kept secret, hidden in bags, baskets, houses. They are only revealed in the initiation context sometimes through dance, dramatic action, music, and song, more rarely through display and contemplation. It must be noted that, with few isolated exceptions (Biebuyck, 1973, 1986), the use of the sculptures is restricted to those rites that lead to the two highest male (yananio and kindi) and female (bulonda, bunyamwa) grades and subgrades. The greatest number of figurines intervenes at the highest rites of the kindi initiations. The wooden ones are kept in baskets, collectively owned and guarded by the most recent kindi initiate in a well-defined ritual community; the ivory/bone ones are individually owned, except for some larger figurines that are also guarded by a most senior kindi on behalf of his ritual community.

11 Most importantly, the sculptures are intimately associated with aphoristic texts, "the words of the land" (bitondo bya kisi). Aphorisms occur at all levels of initiation ${ }^{8}$ from rites in the lowest grade of the kongabulumbu to the final rites in the highest grade of lutumbo lwa kindi (title of the highest level of the bwami initiation). The aphorisms (thousands of them) are complex in symbolic formulation and interpretation. In their form and content, they are extremely succinct, terse, poetic statements (some based on one line, some on two lines, each comprising a certain number of syllables, most commonly 7, 9 or 11 syllables taking into account numerous contractions and elisions).

12 Whereas some seem less cryptic and puzzling than others, the interpretations given by the preceptors and other initiates are always unexpected or surprising for the novice. 
In other words, they are revelatory of privileged knowledge. Except in the supreme rite of bele muno (lit. those who are here in this place [initiation house]) in the lutumbo lwa kindi initiation, where they are implicit, the aphorisms are sung in a dramatic context with musical accompaniment (steel axes, bone pegs, sticks, drums, slit-drum, rattles). During the rites, it is a preceptor (nsingia) who starts the song followed by the choir of participant initiates. Similarly worded or slightly divergent aphorisms are sung at different levels of the rites, but while their interpretation by different preceptors may vary, the texts and their interpretation are intended to formulate and clarify the principles of bwami. They transmit messages contributing to the conveyance and perpetuation of the codes of knowledge and behavior proposed by the bwami membership. This is not a code of abstract philosophical or mythical speculations, but a systematic and practical code of moral behavior and social conduct. The formulation of ideas in the bwami initiation does not depend on elaborate treatises and arguments. There are no complex cosmologies or mythologies to explain. Even references to historical origins and early migrations are limited in scope. The emphasis in bwami is on social conduct and moral behavior, on the greatness of its members, on the immunity and quasi-immortality of the few who achieved the highest initiation, and on the timelessness of the association itself. These ideas are synthesized ad infinitum in terse statements. Because of their succinctness and their possible ambiguity in a dramatic context of music and dance, the aphoristic texts add to the mystery of the initiations and contribute to maintaining the essential elements of secrecy.

The ideas formulated in these succinct aphoristic texts are preserved in and illustrated by a large array of different categories of objects that come into play in the ceremonies. The link between any aphorism and a particular object is difficult to grasp. For the Western observer, collector, scholar, museum expert, the uses, functions and meanings of Lega artworks, mostly collected out of context, are obscure and prone to guesswork. This is abundantly clear in countless publications where elementary, fantastic, and nonsensical ascriptions of function and meaning are given to specific Lega artworks and objects. Even to the Lega noninitiate, the semantic, iconic and symbolic relationship is a puzzle. On the other hand, the initiates, the link and attendant meaning become clear in the initiation context. One example will illustrate:

When the preceptors and initiates dance with a mat (called Katanda), the mat is not only a material object, domestic and mundane, but it personifies a person called Katanda, male or female, exhibiting positive or negative character traits. Moreover, in dance movement, the mat is used in certain ways, conveying esoteric meaning: for example, something that covers symbolizing the bwami that covers everything, something that flies, like an owl, (betrayer of secrets). Young and old Lega know how the mat is made and for what purposes it is used in daily life, however they can only guess what the mat means in the scheme of thinking prevalent in the Bwami initiations.

In the secret initiation context, discourse and object are inseparable. From certain points of view the objects are the tangible expression of the teachings; they are mnemonic devices in that they are associated with specific ideas and values. Yet, the aphorisms can be said to be more powerful permanent than the objects themselves which can decay, burn, be accidentally destroyed. The replacement figurine may be similar or entirely different from the lost one, whereas the original association with a specific aphorism remains. 
ple examples of aphorisms sung in conjunction with exuviae show a rather direct relation between the form and type of object used and the corresponding text and interpretation, as illustrated in following examples:

Aphorism: "Kikoku (Water Snail, personified), my maternal uncle, helps me cross the rapids."

Context: The preceptor dances with the large shell of an aquatic snail.

Meaning: Emphasizes the help and advice one can always expect, outside one's patrilineal group, from maternal uncles (not simply uterine maternal uncles, but those belonging to mother's or mother's mother's or father's mother's group).

Aphorism: "Where Kuboko (Arm) cannot reach, Igobo (Hooked Perch) does reach."

Context: Preceptors dancing with a hooked perch

Meaning: Refers to cooperation; one kinsman helps another; one expects help and support from a maternal uncle.

The links between the figurines and the associated aphorisms, in contrast to the exuviae, are never simple or straightforward. Many sculptures are so generalized in form that there is no way of telling which aphorism they illustrate unless the owner himself made the identification in the initiation context. Consequently, similar looking statues are identified differently by their owners. Some sculptures may even represent two or more contradictory characters.

The wooden statues occur in a context of dance and drama. Those contained in collectively held baskets, the simultaneous use of two or more sculptures handled in a dance context and the overall purpose of the rite determine the meanings expressed in the aphorism and the figurine.

In the mutulwa rite of the kindi initiations, ${ }^{9}$ the contents of a collectively held basket are displayed on the ground in a configuration and then, one by one, or two by two, the objects are picked up by the preceptors who dance, gesture, and mimic. In this case, the display includes animal exuviae (the skull of a chimpanzee and of a leopard, a small and old darkened female elephant tusk that is not sculpted) and sculptures (a small phalluslike peg in bone, a double-faced wooden half figurine, a wooden female figurine with distended belly, a wooden standing figurine wearing a skullcap made of a cercopithecus monkey hide, a crude horizontally placed figurine with an enema in the buttocks, a standing bird figure). Each of these objects is danced with, mostly two or three at a time, such that meaning is derived from the relations between the objects themselves, their associated aphorism, and the action context. For example: ${ }^{10}$

The half figurine and the cap-wearing one are danced with simultaneously, each one held in the hand by a preceptor who points to them in a gesture of disapproval. In this sequence, the half figure is identified with a certain character called Mukobanya (a high initiate), the divider, a term with positive and negative connotations (one who created divisions among people; one who distributes foods, game adequately among kin and initiates). The cap-wearing figurine is identified as Kakulu ka Mpito, Dear-Little-Old-One-with-the-Mpito-cap (another high initiate). The preceptors interpret the scene as follows: Mukobanya sowed discord because he invited people to a beer party that turned into a brawl. In this brawl, Kakulu ka Mpito "died early in the morning"; i.e., he died a bad death, meaning that he was injured or that he belittled himself by participating in this kind of party, in which a wise initiate should never partake.

In the same sequence, the standing bird figurine is identified as Kakulikuli, talkative bird, personified as an individual who runs into trouble because he is nosy and talks too much, and therefore causes tension and distress. It is danced together with the piece of ivory tusk identified as Mulamba, a young woman who runs 
around with men and finds trouble in her path or sometimes a restless young man whose vagaries end in tragedy.

The entire configuration of exuviae and wooden sculptures is intended to illustrate Bwami values ex contrariis: a true initiate, male or female, is not like any of the above mentioned characters. The rite is intended as a warning to those who deviate from the norms of conduct: the high initiate who witnesses this rite is aware of the values of restraint represented in this drama; he has heard them again and again, as they were formulated in different ways and contexts in previous lower initiations. The present rite is a reminder that a high initiate must be a person of good judgment, someone who should not sponsor candidates who exhibit these flaws. or verbal commentary. The connection between a given aphorism and these figurines is even more abstract because nothing is revealed about the piece itself. Certain features of form (e.g., multiple faces or heads, one arm or one-eye) apparently show some connection with the associated aphorism, but in the vast majority of cases, no immediate link between statuette and text can be detected. It can be said that the association is based on purely traditional, historical, invented, conventional, unexplainable perceptions. For example:

A small a-sexual figurine is associated with the following aphorism: "Kakinga, maiden was beautiful (and good); adulterous behavior has destroyed her." The same aphorism is linked in different communities with small ivory figurines of different morphology, with or without sexual markings.

\section{Kakinga, maiden was beautiful (and good)...}

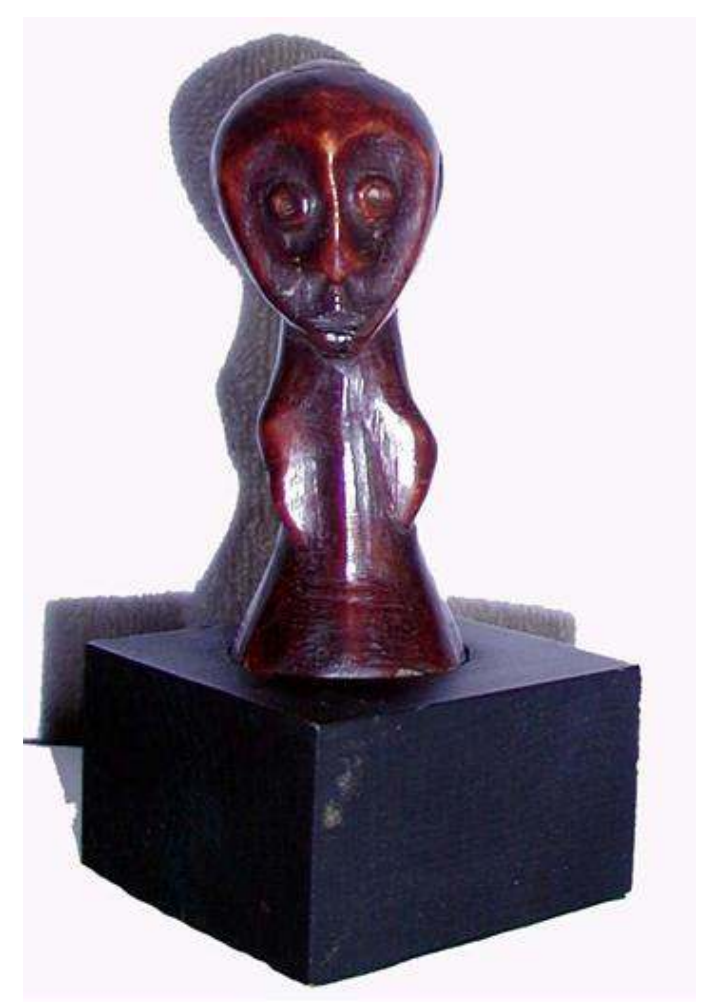

Daniel P. Biebuyck received this piece at the end of the supreme kindi initiation rites of the closed bwami initiation

Private collection

Another full standing a-sexual figurine evokes the ideal kindi in the aphorism "The One-who-forges-himself (Keitula), son of Great Singer, a Beautiful-one to be seen." 
The text and sculpture recall the great kindi initiate, strong but fait and good, "a person whom many join for support and protection," because "he is a true leader who 'forges' durable bonds that transcend kinship."

\section{The One-who-forges-himself (Keitula)...}

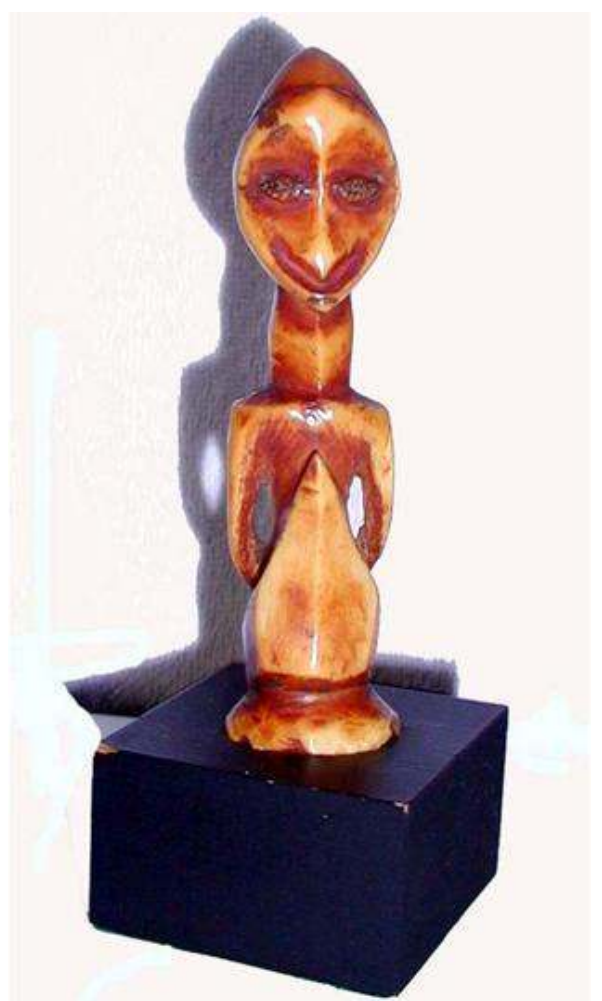

Daniel P. Biebuyck received this piece at the end of the supreme kindi initiation rites of the closed bwami initiation

Private collection

Yet another stylized, a-sexual, ivory figurine shows no connections with the meanings attached to it. It is identified by its owner as: "Mrs Small Barkcloth Aprons (Nyatulondo twa nsulu), the one who urged you to make the trip (i.e., who induced you to go to the initiation)." Nyatulondo is a woman who goes to the initiations with seductive intentions. In general, she represents a wife of bad habits and an initiate should not take such a woman with him to the rites. It is to be noted that the character of Nyatulondo is already dramatically presented in the lower initiation rites of the bombwa grade. A woman of the highest grade dances wildly swinging pieces of barkcloth tied to her belt, while male initiates move towards her as if trying to touch her sex.

A figurine with one arm and two faces (symbol of the high initiate as a man of knowledge and discernment) is identified as Kuboko kumozi (One-arm) and represents an initiate who is meddlesome, got into a brawl, and was physically and morally damaged (a high initiate is a non-violent person). ${ }^{11}$ 


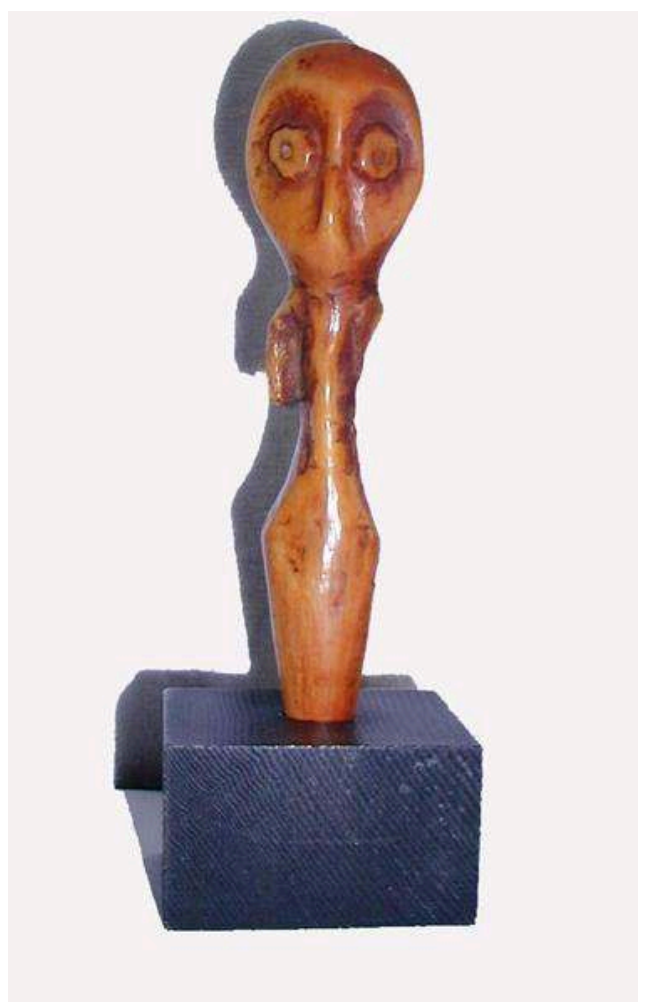

Daniel P. Biebuyck received this piece at the end of the supreme kindi initiation rites of the closed bwami initiation

Private collection

At the end of the ultimate kindi rite of "those who are here with us" (bele muno) - in what must be viewed as the ultimate epopteia (having-seen/witnessed, revelation) - the new initiate receives, through the medium of his initiated tutor, a figurine as a symbol of his newly acquired rank and status. In the majority of cases, this object is said or thought to have belonged to a deceased kinsman who is conventionally referred to as "father," i.e., an agnatically related predecessor in the grade now coveted by the initiand. The tutor is a kindi initiate, related or not related, who acted as "guardian of the tomb" of the deceased kindi and thus became the custodian of the initiation objects left by him. The figurine is thus not only an exclusive insignia of the highest rank and status but an expression of the perpetual bond between close and remote kinsfolk, alive or dead. It is also the ultimate, most secret synthesis of the highest values. Since the figurine is thought to be "inherited" from a predecessor, the origin of a particular textual and iconic association cannot be traced. As a Lega bwami aphorism states: "What has been found already in existence, cannot be/must not be explained." The relationship is historical, traditional; it is a given.

This bele muno rite is attended only by the initiand (who in previous years has already gone through many initiations leading up to this supreme moment) and initiates of the lutumbo lwa kindi grade. The ivory/bone figurines are displayed inside the initiation house either in front of every seated kindi or in a small configuration set up in their midst. At all other previously witnessed initiation rites, the aphorisms were sung, but not at this highest rite, during which the ivory figurines are exhibited and one of them is transferred to the initiand. Here, at the moment of "the highest accomplishment," 
there is no dancing, no singing, no drama, only contemplation and some sort of mystic communion among all kindi, alive and dead. The initiand receives his figurine from his tutor together with its traditional aphorism. For the rest, no explanations are given. Most of the participants have already in past initiation rites seen the sculptures of their colleagues and know what they are all about. If they have not seen them before, they can ask or not ask about it when they engage in oiling the ivory figurines, gather in the men's house or sit together in small groups. ${ }^{12}$

At this highest level of initiation, the initiand has seen and heard it all: the values and non-values have been illustrated and interpreted for him in countless rites. The secret of meaning(s) implied by the figurines is total, no further exegesis is appropriate. The figurines are displayed by their owners and passed around in the closed initiation house. Their name is embedded in an aphorism - a name that points to a positive or negative character requiring no further explanation.

In their exegesis of the aphorisms, the preceptors recommend a number of moral and behavioral principles that are preeminent for the initiates: to undergo the circumcision rite (bwali), to marry (isonga), to engender (ibuta) and to "learn" the initiation of bwami (isima mpala). Code and exegesis stress the rules of etiquette; the inseparable bond between husband and wife, between kindi and kanyamwa (like tibia and needle, needle and raffia thread, handle and axe); solidarity in the agnatic kinship group and in the relationships with matrilineally connected individuals and groups; promise of greatness, power, immunity and quasi-perenity; respect for and solidarity with father, mother, seniors, elders, kinsfolk. They praise the beauty, serenity, and peacefulness of the initiations, in contrast to such disruptive actions as gambling, poison ordeal, divination, adultery, disorderly behavior, vagrancy, violence, witchcraft, sorcery, thievery, deception, rebelliousness of women, and lack of filial piety. In the aphorisms, the preceptors tirelessly underscore the qualities of effort, tenacity, perseverance, moderation, equity, discretion, circumspection, verbal restraint, sense of duty, sense of honor, cooperation, hospitality, generosity, conviviality, non-violence, order, humanity, prudence, circumspection, while at the same time rejecting hubris, atê, arrogance, hypocrisy, aggressiveness, rawness of heart, pathos, vagabondage, meddlesomeness, vagabondage, adultery, witchcraft, violence, arrogance, disobedience, lack of respect for elders.

The male and female characters associated with ivory figurines are either positive or negative exemplifications of the aforementioned ethical code of bwami. Among the hundreds of such characters, one finds such positive male figures as Itamba (Moderator), Kankubungu (Good-Beaufiful-one), Kigamba (physically and morally Strong-one), Kimini (Great Dancer) and such negative ones as Isabulema (FatherMisery), Isabulumbu (Father-Blinded-by-Hate), Isabumania (Father-Lust), Isakasumo (Father-Spear, i.e., Violent-one). Among the positive female characters, there is Kikumi (Young maiden), Kalonda (Beautiful-one), Mulamba (Ivory). The negative ones include Nyabeidilwa (Mother Overcome by Night), Nyabilimbio (Mother Buttocks), Minna (Angry one).

It is striking that much of the teaching in bwami proceeds ex contrariis. Whereas many of the characters occurring in the aphorisms represent negative behavioral traits, the exegesis (explicit or implicit) proposes the right conduct. This mode of presenting ideas adds to the essential secrecy of the initiations. 
Within the bwami association, the relationships between object, text, and context constitute an essential aspect of the "ineffable secret" that is revealed only in the closed context of the initiations. This is, a fortiori, true of the wooden and ivory/bone sculptures which are exclusive, unseen, "dangerous" and privileged possessions of the highest male and female initiates. Everything that is said and done in the initiations has meaning or, as the Lega express it: "In the wickerwork rattle, every seed speaks." But an object by itself "does not speak"; form has no intrinsic meaning. Its meaning is created and it varies according to situation, configuration, perspective, and one's level of knowledge. The meaning of words and objects is nuanced, clarified, and amplified through the initiation context in which they are sung, the configurations and sequences in which they occur, the dance movements and gestures that complement them. Ultimately, meaning is conveyed in a context of initiation by the interplay of objects, words, dance, music, and song.

\section{BIBLIOGRAPHIE}

1953, Signification d'une statuette lega. Revue coloniale belge 195 : 866-867.

1954, Function of a Lega Mask. Archives internationales d'ethnographie 47: 108-120.

1957, L'art des Balega. Jeune Afrique 10, nº 25: 15-17.

1965, African Sculpture: An Anthology, by W.B. Fagg and M.W. Plass. Man, May-June 1965: 93-94.

1968, Art as a Didactic Device in African Initiation Systems. African Forum 3: 35-43.

1972, The Kindi Aristocrats and their Art among the Lega. In African Art and Leadership, edited by

D. Fraser and H. Cole. Madison: University of Wisconsin Press: 7-20.

1973, Lega Culture: Art, Initiation, and Moral Philosophy among a Central African People. Berkeley and Los Angeles: University of California Press. 268 p. and 110 pls. Large syntheses based on this book may be found in Brain, Cameron, Hunn, Layton, Smith and Perani. In African art books, catalogues of exhibitions and of sales, this is one of the most frequently mentioned works on African Art.

1979, The Frog and Other Animals in Lega Art and Initiation. Africa-Tervuren 25: 76-84.

1981, Plurifrontal Figurines in Lega Art (Zaire). In The Shape of the Past: Studies in Honor of Franklin D. Murphy, edited by G. Buccellati and Ch. Speroni. Berkeley and Los Angeles: University of California Press: 115-127.

1983, Lega Spoons. In Liber Memorialis for Professor Vandenhoutte, edited by H. Burssens. Ghent: State University: 51-66.

1985, The Arts of Zaire. Southwestern Zaire, vol. 1. Berkeley and Los Angeles: University of California Press. 416 p. and 100 pls.

1986, The Arts of Zaire. Eastern Zaire: The Ritual and Artistic Contexts of Voluntary Associations, vol. 2. Berkeley and Los Angeles: The University of California Press, 331 p. and 98 pls. 
1993, Masks and Initiation among the Lega Cluster of Peoples. In Het Gelaat van de Geesten: Maskers uit het Zaire Bekken, edited by Frank Herremans and Constantijn Petridis. Antwerp: Etnografisch Museum. Translated as Face of the Spirits. Masks from the Zaire Basin: 183-197.

1994, Lega Sculpture. Sculpture lega. Paris and New York: Galerie Hélène and Philippe Leloup. 203 p., including 87 pls. French text by Brunhilde Biebuyck and Mihaela Bacou.

1999, The Words of the Land. Teaching through Proverbs. Cahiers de littérature orale 45: 111-146. 2002, Lega. Ethics and beauty in the heart of Africa. Gent: Snoeck-Ducaju \& Zoon (Separate editions in Dutch and in French).

\section{NOTES}

1. Piptadenea Africana.

2. About the universality of the bwami association in Legaland.

3. The initiates speaking to noninitiates: "You see certain external things (like the paraphernalia we wear), but you know nothing about what happens in the initiation house."

4. To say that not every initiate has the mental and moral aptitude to achieve the supreme initiations of kindi.

5. Like the initiates (bami) do when they rub their bodies daily with a light mixture of castor oil and red powder.

6. The unexpected use of masks and maskettes at final rites poses exceptional problems of interpretation, when they are not observed in their dramatic contexts (for uses, functions and meanings of masks, see Biebuyck, 1973, 1985, 2002).

7. The term kisi also implies the idea of power, control, plenitude.

8. A limited number of aphorisms presented in the initiation context are also quoted outside the bwami rites (e.g. in the mutanga teachings of the youth, see Biebuyck, 1999), but their exegesis is simpler, more superficial, conceived as an introduction to a deeper reality.

9. Here we are only referring to wooden figurines and other items in collective ownership.

10. For a detailed analysis of these examples, see Biebuyck $(1973,2002)$, text and photos.

11. For more examples, see Biebuyck (1965: 91-96; 1985).

12. This is exactly what I myself had to do. When the highest initiation was finished, when I paid them the fees due or distributed gifts and the initiates started to disperse, I would ask the kindi present for the name and appropriate aphorism associated with the figurine in his possession, and what it really meant for him. Answers were prompt and clear without hesitation.

\section{RÉSUMÉS}

Chez les Lega du Sud-Kivu, chaque objet, naturel ou fabriqué, qui figure dans les initiations de l'association bwami est, au minimum, associé à un aphorisme. Les objets ne sont pas nécessairement identifiés aux aphorismes pour ce qu'ils sont mais pour les concepts qu'ils représentent. Ces derniers renvoient tant à des principes sociaux et moraux qu'au pouvoir, à la grandeur de l'association et de ses initiés. Sachant que ces initiations sont secrètes, le rapport 
entre un objet et son aphorisme ainsi que leur interprétation est impossible à déterminer en dehors du contexte initiatique.

Among the Lega of southern Kivu, each object, be it natural or fabricated, in the initiations to the bwami association is associated with at least one aphorism. The latter refer to social, moral, political principles and to the greatness of the association and its initiates. It is impossible to interpret the meaning of these aphorisms and their relationship to the objects outside of the initiation context.

\section{INDEX}

Index géographique : Afrique centrale, Sud-Kivu

Keywords : Lega, Initiation, Ritual, Bwami Association, Sculptures, Aphorisms, Moral Philosophy, Anthropology, South Kivu, Central Africa

nomsmotscles Lega

Thèmes : anthropologie (Afrique)

Mots-clés : initiation, rituel, association Bwami, sculpture, aphorismes, philosophie morale 